\title{
A novel mcl PHA-producing bacterium, Pseudomonas guezennei sp. nov., isolated from a 'kopara' mat located in Rangiroa, an atoll of French Polynesia
}

\author{
C. Simon-Colin ${ }^{1, *}$, K. Alain ${ }^{2}$, S. Colin ${ }^{1}$, J. Cozien ${ }^{1}$, B. Costa ${ }^{3}$, J.G. Guezennec ${ }^{1}$, G.H.C. Raguénès ${ }^{1}$ \\ France \\ ${ }^{1}$ Institut Français de Recherche pour l'Exploitation de la Mer, Centre de Brest, BIOMAR/BMM, Plouzané, \\ ${ }^{2}$ Laboratoire d'Océanographie Biologique de Banyuls, Equipe d'Ecologie Microbienne Marine, Banyuls sur \\ Mer, France \\ ${ }^{3}$ Biolib, Arue, Tahiti, Polynésie Française, France \\ *: Corresponding author : C. Simon-Colin, email address : christelle.simon.colin@ifremer.fr
}

\begin{abstract}
:
Aims: The aim of the present study was to describe an aerobic, mesophilic and heterotrophic bacterium, designated RA26, able to produce a medium-chain-length polyhydroxyalkanoate (PHA). It was isolated from a French Polynesian bacterial mat located in the atoll of Rangiroa.

Methods and Results: This micro-organism, on the basis of the phenotypical features and genotypic investigations can be clearly assigned to the Pseudomonas genus and the name of Pseudomonas guezennei is proposed. Optimal growth occurs between 33 and $37^{\circ} \mathrm{C}$, at a pH between 6.4 and 7.1 and at ionic strength of $15 \mathrm{~g} \mathrm{I}-1$ of sea salts. The $\mathrm{G}+\mathrm{C}$ content of DNA is $63.2 \%$. Under laboratory conditions, this bacterium produced a novel, medium-chain-length PHA, mainly composed of 3hydroxydecanaote (64 mol.\%) and 3-hydroxyoctanoate (24 mol.\%) (GC-MS, NMR) from a single nonrelated carbon substrate, i.e. glucose.

Conclusions: The bacterium P. guezennei produces a novel PHA mcl with elastomeric properties.

Significance and Impact of the Study: PHAs share physical and material properties that recommend them for application in various areas, and are considered as an alternative to nonbiodegradable plastics produced from fossil oils. In this study, we describe a new bacteria with the capability to synthesize a novel PHA with promising biotechnological applications.
\end{abstract}

Keywords: microbial mat - « kopara » - Pseudomonas - PHAs - polyhydroxyalkanaote 


\section{Introduction}

Marine microbial mats are encountered in a large variety of sites all over the world. They are also found in some atolls of French Polynesia (Andréfouët et al. 2003), where they are called 'kopara'. These environments are known to produce a large number of viscous laminated layers in which the presence of exopolysaccharides secreted by the microbial communities has been demonstrated (Mao Che et al. 2001; Rougeaux et al. 2001) in response to the high fluctuation of environmental conditions of those mats (salinity, temperature, $\mathrm{pH}$, etc.).

Because of their thermoplastic properties and biodegradability, polyhydroxyalkanaotes (PHAs) have attracted industrial interest and have been extensively studied in the last two decades. For reviews, see Hocking and Marchessault (1994), Steinbüchel and Valentin (1995), Hankermeyer and Tjeerdema (1999), Braunegg et al. (1998) and references cited therein. PHAs comprise a large class of polyesters that are accumulated in a wide variety of bacteria as carbon and energy storage material. The polymers are deposited intracellularly in the form of inclusion bodies (granules) and might amount up to 90\% of the cellular dry weight (Anderson and Dawes 1990; Doi 1990) if the bacteria are cultivated in the presence of excess carbon and if one nutrient limits growth. The monomeric composition of PHAs depends on the bacterial strain and on the carbon source supplied. PHAs can be divided into three groups depending on the number of carbon atoms in the monomeric units: short-chain-length PHA (3-5 carbon atoms, PHASCL), mediumchain-length (6-15 carbon atoms, PHAMCL) and long-chain-length (more than 15 carbon atoms, $\mathrm{PHA}_{L C L}$ ). Bacterial PHAs are probably the largest group of thermoplastics known and their properties are similar to those of petrochemical plastics, including materials that resemble polypropylene and others that are elastomeric. Typically, PHAs with short-chain-length such as 3polyhydroxybutyrate $(\mathrm{PHB})$ are highly crystalline and stiff material and are brittle and have poor elastic properties. These properties limit their range of applications, whereas longer chain are more ductile and easier to mould.

In addition to being tremendous potential substitutes for petrochemical plastics, PHAs are produced naturally from renewable carbon sources and represent a new way of utilizing waste from low-cost carbon stocks (Solaiman et al. 2001; Tsuge 2002; Ashby et al. 2004, 2005; Koller et al. 2005). However, the most attractive feature of PHAs is their biodegradability to CO2 and $\mathrm{H} 2 \mathrm{O}$, resulting from the pure chirally R-configuration that create environmentally friendly plastics.

The aim of this study was to describe a new PHA-producing strain designated as RA26 which was isolated from a 'kopara' mat of the Rangiroa atoll. Under stress conditions and in the presence of suitable carbon substrate in excess, this bacterium was shown to produce a biopolymer of biotechnological interest.

\section{Materials and methods}

\section{Bacterial strain}

In November 2001, many samples of 'kopara' were collected from the different microbial mats located on the atoll of Rangiroa (Raguénès et al. 2004). Enrichment cultures were purified on Marine Agar 2216E (Difco Laboratories, Detroit, MI, USA). RA26 was selected because of its capacity to exhibit a different phenotype on Minimum Marine Agar Medium (Sigma Sea Salts $27 \mathrm{gl}-1$, agar $15 \mathrm{gl}$-1 and $\mathrm{pH}$ 7.6; Sigma-Aldrich, St Quentin, France) supplemented with $20 \mathrm{~g} \mathrm{I}^{-1}$ of glucose. 


\section{Reference strains}

Pseudomonas aeruginosa type strain $\left(\mathrm{DSM} 50071^{\top}\right.$ ) was purchased from DSMZ collection (Hamburg, Germany).

\section{Characterization of the bacterium}

Isolation procedures, physiological characterizations and DNA base composition were performed as described by Raguénès et al. (1997). For phylogenetic characterization, the 16S rRNA gene was double-strand sequenced by CAMBREX S.A. (Biopôle Clermont-Limagne, Saint Beauzire, France). The phylogenetic analysis was performed with the arb program package of the Technical University of Munich (http://www.arb-home.de). A total of $1379 \mathrm{bp}$ were sequenced and then a total of $1379 \mathrm{bp}$ were added to an alignment of c. 10000 homologous bacterial 16S rRNA primary structures by using the aligning tool of the arb program package and the alignment was refined manually. Phylogenetic reconstruction was performed with the following settings as implemented in the arb software: neighbour-joining with the correction of Kimura, Maximum Parsimony and Maximum Likelihood. Different sets of filters were evaluated for the reconstruction. A consensus tree was constructed based on the topologies derived from these different analyses.

The quantitative DNA reassociations between $P$. aeruginosa type strain and strain RA26 were determined by spectroscopic DNA-DNA hybridization: DNA was isolated using a French pressure cell (Thermo Spectronic, Vitroles, France) and was purified by chromatography on hydroxyapatite as described by Cashion et al. (1977). DNA-DNA hybridization was carried out as described by De Ley et al. (1970) with modifications described by Huss et al. (1983) using a model Cary 100 Bio UV/VIS-spectrophotometer (Varian, Les Ulis, France) equipped with a Peltier-thermostatted $6 \times 6$ multicell changer and a temperature controller with in-situ temperature probe (Varian).

\section{Transmission electron microscopy}

Cells were recovered by centrifugation ( $8500 \mathrm{~g}$ for $20 \mathrm{~min}$ ) after 3 days of culture. The pellet was resuspended and fixed for $1 \mathrm{~h}$ in $2.5 \%(\mathrm{v} / \mathrm{v})$ glutaraldehyde. The immobilized cells were washed three times with sea water, $75 \%$ and postfixed with osmium tetraoxide for $1 \mathrm{~h}$. After dehydration by immersion in an increasing ethanol concentration series, cells were embedded in Spurr's resin, thin-sectioned, contrasted with $1 \%(\mathrm{w} / \mathrm{v})$ uranyl-acetate and $1 \%(\mathrm{w} / \mathrm{v})$ lead citrate (Bio-Rad, Marne la Coquette, France) and then examined with a 100 CXII transmission electron microscope (Jeol, Croissy sur Seine, France).

\section{Production, isolation and purification of RA26 PHA}

PHA production was performed in two steps. A 5-I fermenter (Infors, Massy, France) containing 3 I of marine broth (per litre: $5 \mathrm{~g}$ peptone, $1 \mathrm{~g}$ yeast, $15 \mathrm{~g}$ sea salts) was inoculated at $10 \%(\mathrm{v} / \mathrm{v})$ with a suspension of cells in exponential phase. The temperature was maintained at $35^{\circ} \mathrm{C}$ and the $\mathrm{pH}$ was adjusted at 7.0 by automatic addition of $2 \mathrm{~mol} \mathrm{I}^{-1} \mathrm{NaOH}$. The air flow was fixed at $30 \mathrm{I} \mathrm{h}^{-1}$ and the agitation rate from 200 to $400 \mathrm{rpm}$ to maintain the level of dissolved $\mathrm{O}_{2}$ at approx. $25 \%$. After centrifugation ( $5000 \mathrm{~g}$ for $40 \mathrm{~min}$ ), the cell pellets were transferred into the same 5-I fermenter containing $3 \mathrm{I}$ of Sea Salts broth supplemented with sugar (per litre: $20 \mathrm{~g}$ glucose, $15 \mathrm{~g}$ Sea Salts) and maintained under the same culture conditions. PHA polymers were recovered from the pellets and lyophilized prior to further analysis. 


\section{Chemical analysis}

\section{PHA isolation and characterization}

Dried frozen cells recovered from the pellet were ground in a mortar and the powder was extracted with chloroform for $4 \mathrm{~h}$ at $50^{\circ} \mathrm{C}$. The PHA-containing chloroform was concentrated and extracted once with water to remove residual solid particles. The organic phase containing PHA polymers was evaporated to dryness and the resulting crude extract preserved for further analyses.

\section{GC-MS analysis}

Samples of polymer were subjected to methanolysis in the presence of $\mathrm{MeOH} / \mathrm{HCl}(17 / 2, \mathrm{v} / \mathrm{v})$ at $100^{\circ} \mathrm{C}$ for $4 \mathrm{~h}$. After phase separation and two washes with water, the organic phase was dried under nitrogen. TMS derivation of 3-hydroxyalkanoate methyl esters was accomplished by adding $100 \mu \mathrm{l}$ pyridine and $100 \mu \mathrm{l}$ BSTFA (N,O-bis-(trimethylsilyl)trifluoroacetamide) to $1 \mathrm{ml}$ methanolized sample. The reaction mixture was heated at $70^{\circ} \mathrm{C}$ for $45 \mathrm{~min}$. The TMS derivatives of methyl esters of monomer constituents were analysed by GC-MS using an Agilent 6890N chromatograph coupled to a quadrupole Agilent 5975 inert XL mass selective spectrometer (Agilent, Mossy, France), equipped with a HP-5-MS fused silica capillary column (30 $\mathrm{m} \times 0.25 \mathrm{~mm}, 25 \mu \mathrm{m}$ film thickness) with helium as carrier gas. The ionizing energy for MS operation was $70 \mathrm{eV}$.

\section{Lipid analysis}

Lipids were extracted from lyophilized cells $(50 \mathrm{mg})$ using a modified Bligh and Dyer method. The extracted lipids were fractioned into neutral, glycolipids and polar lipids by silicic acid column chromatography using a series of solvents of increasing polarity: dichloromethane, acetone and methanol. Fatty acid methyl esters were prepared from the esterified lipids in the polar (methanol) fraction by mild acid methanolic transesterification and analysed by GC-MS under the same conditions as described above. Identification of fatty acids methyl esters was based on comparison of relative retention times and mass spectra of standards. Double bond position and geometry of monounsaturated fatty acid methyl esters were determined after the formation of dimethyldisulfide adducts prepared according to methods described previously (Nichols et al. 1986).

Fatty acids are designated by the total number of carbon atoms: number of double bonds, followed by the position of the double bond from the terminal $(\omega)$ end of the molecule. The suffixes $\mathrm{c}$ and $\mathrm{t}$ indicate cis and trans geometry.

\section{Results}

\section{Morphology}

Strain RA26 was a motile, strictly aerobic, nonfermentative, Gram-negative rod, 0.6 by $2.2 \mu \mathrm{m}$ size. Microscopic observation performed on cells during the accumulation of PHAs clearly shows the existence of intracellular PHA granules (Fig. 1).

\section{Cultural conditions}

The optimal temperature for growth was between 33 and $37^{\circ} \mathrm{C}$, the optimal $\mathrm{pH}$ was between 6.4 and 7.1 and the optimal ionic strength was between 15 and $20 \mathrm{~g} \mathrm{I}^{-1}$ of Sea Salts. The doubling time, under optimal conditions, was 35 min. 


\section{Metabolic properties}

Tests were performed using API20NE, APIZYM, ATB VET strips and Biolog GN microplates. Reduction of nitrates to nitrites, presence of protease (gelatin) and assimilation of glucose, capric acid, malate, trisodium citrate, phenylacetic acid were observed on API20NE. Esterase (C4), esterase lipase (C8), lipase (C14) and leucine aryladimase were detected on APIZYM. Antibiotics susceptibility tests (ATB VET) showed that strain RA26 was sensible to streptomycin, spectinomycin, kanamycin, gentamicin, apramycin, tetracycline, doxycycline, colistin, clotrimoxazol, sulfamethizol, flumequin, oxolinic acid and enrofloxacin. As a result for the Pseudomonas genus, we can note on Biolog GN the nonutilization of glycerol.

\section{DNA base composition}

The $\mathrm{G}+\mathrm{C}$ content of strain RA26 was $63 \cdot 2$ mol. $\%$.

\section{Phylogenetic analyses}

The sequence of the 16S rRNA-encoding gene of strain RA26 was determined (1379 bp) and deposited in the EMBL sequence database under accession number AJ876736. Phylogenetic analyses using the arb program showed that strain RA26 belonged to the gamma subdivision of the phylum Proteobacteria and that it was closely related to P. aeruginosa. More analyses were performed using the sequences of the type strain of the genus Pseudomonas. Results are shown in Fig. 2. All three methods used (neighbour joining, maximum parsimony and maximum likelihood) placed RA26 in a monophyletic group with P. aeruginosa. The percentage sequence similarity between RA26 and P. aeruginosa was $99 \%$, clearly above the limit of intraspecies variability (97\%) as proposed by Stackebrandt and Goebel (1994). Nevertheless, we conducted quantitative DNA-DNA hybridization to confirm RA26 as a new species of Pseudomonas.

\section{DNA reassociation}

The measurement of DNA-DNA homology between strain RA26 and the most closely related Pseudomonas as deduced from the phylogenetic analysis showed a homology value of $28.4 \%$ with $P$. aeruginosa. Taking in consideration the criteria recommended by Wayne et al. (1987), this result confirmed strain RA26 as a new species of Pseudomonas.

\section{Lipid analysis}

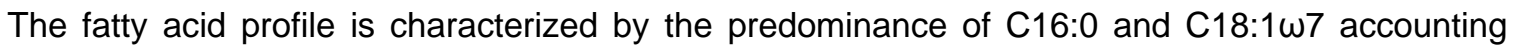
from $44.2 \%$ and $40.3 \%$ of the total acids, respectively, along with C16:1(w)7c (12.9\%). Others fatty acids were present at lower concentrations, i.e. C14:0 (1.4\%), C15:0 (0.4\%) and C18:0 $(0 \cdot 8 \%)$.

\section{Production of PHA}

During the batch fermentation of strain RA26, the production of PHA began after $34 \mathrm{~h}$ in glucoseenriched medium and stopped after 3 days. Under these conditions, the yield of PHA produced was near $250 \mathrm{mg} \mathrm{I}^{-1}$, with granules filling about $80-90 \%$ of the cellular volume.

\section{Characterization of PHA}

Six different TMS derivative methyl ester peaks were found for the PHA isolated from glucose grown strain RA26, with retention times of $7.3,12.4,18.2,23.07,25.2$ and 25.4 min. These monomers were analysed in GC-MS and identified as 3-hydroxybutyrate (3HB), 3hydroxyhexanoate $(3 \mathrm{HHx}), \quad 3$-hydroxyoctanoate $(3 \mathrm{HO}), \quad 3$-hydroxydecanoate (3HD), 3- 
hydroxydodecenoate (3Hdde) and 3-hydroxydodecanoate (3HDd), respectively. The mass spectra of TMS derivatives of 3-hydroxyalkanoic acid methyl esters exhibited characteristic fragments at m/e $175\left(\left(\mathrm{CH}_{3}\right)_{3} \mathrm{SiO}^{+}=\mathrm{CHCH}_{2} \mathrm{CO}_{2} \mathrm{CH}_{3}\right)$ and m/e [M-73] $\left(\mathrm{RCH}=\mathrm{O}^{+} \mathrm{Si}\left(\mathrm{CH}_{3}\right)_{3}\right)$ because of the cleavage $\alpha$ to the derivatized hydroxyl group.

The composition of PHA synthesized by strain RA26 from glucose was found to consist of $0.3 \mathrm{~mol} . \% 3 \mathrm{HB}, 1.2 \mathrm{~mol} . \% 3 \mathrm{HHx}, 24.1 \mathrm{~mol} . \% 3 \mathrm{HO}, 64.5 \mathrm{~mol} \% 3 \mathrm{HD}, 5.9 \mathrm{~mol} . \% 3 \mathrm{Hdde}$ and 3.9 mol.\% 3HDd as identified by GC-MS.

\section{Discussion}

On the basis of morphological information, cultural studies, biochemical data and $\mathrm{G}+\mathrm{C}$ content, a strictly aerobic, mesophilic, heterotrophic new bacterium isolated from a polynesian 'kopara' mat clearly belongs to the genus Pseudomonas. Phylogenetic analyses of 16S rDNA demonstrated that this bacterium grouped with $P$. aeruginosa, a well-defined taxon that deserves the rank of species. As the measurement of genomic DNA-DNA homology revealed a relatedness well below $50 \%$ between the two bacteria, it is appropriate to conclude that RA26 is a member of a new Pseudomonas species. The name of $P$. guezennei is therefore proposed for the new organism.

The chemical composition of the PHA accumulated by RA26 strain appeared to be different from those produced by other bacteria from extreme environments. A large screening performed on bacteria collected from either deep-sea hydrothermal vents or microbial mats led to the discovery of a significant number of PHA producing micro-organisms. Nevertheless, none of these microorganisms were able to produce PHA mcl using glucose as sole carbon source. PHB and/or PHB/PHV biosynthesis in different ratios were observed for all the extremophiles. rRNA group I Pseudomonas species are well known to biosynthesize medium-chain-length polyhydroxyalkanoates, but relatively few produce this distinct group of PHA using glucose as sole carbon source for both growth and polymer accumulation (Langeveen et al. 1988; Jiang et al. 2006).

\section{Description of P. guezennei sp. Nov}

Pseudomonas guezennei (guez.en.nei N.L. gen. n. guezennei in honour of Jean Guezennec, a great figure of Marine Biotechnology). Cells are Gram-negative, motile short rods that are $0.6 \times 2.2 \mu \mathrm{m}$. Colonies on Marine Agar are circular, convex and smooth. Strictly aerobic. Catalase and oxidase are positive. Growth occurs at $20-40^{\circ} \mathrm{C}$ but not at $4^{\circ} \mathrm{C}$ and weakly at $10^{\circ} \mathrm{C}$. The $\mathrm{G}+\mathrm{C}$ content of the DNA is $63.2 \%$. DNA-DNA homology with $P$. aeruginosa type strain is $28.4 \%$. Isolated from a 'kopara' mat located on the atoll of Rangiroa (French Polynesia). The type strain $P$. guezennei has been deposited in the Collection Nationale de Culture de Microorganisms (Institut Pasteur, Paris, France) as strain CNCM I-3358.

\section{Acknowledgements}

The authors thank the Cairap SA (Arue, Tahiti) for financial support, Serge Andrefouet (University of South Florida, St Petersburg, FL) for its contribution to the ground localization of the mats. We also thank Dr Gérard Sinquin for technical support in transmission electron microscopy.

\section{References}

Anderson, A.J. and Dawes, E.A. (1990) Occurrence, metabolism, metabolic role, and industrial use of bacterial polyhydroalkanoates. Microbiol Rev 54, 450-472. 
Andréfouët, S., Hochberg, E.J., Payri, C., Atkinson, M.J., Muller-Karger, F.E. and Ripley, H. (2003) Multi-scale remote sensing of microbial mats in atoll environment. Int J Remote Sens 24 , 2661-2682.

Ashby, R.D., Solaiman, D.K.Y. and Foglia, T.A. (2004) Bacterial poly(hydroxyalkanoate) polymer production from the biodiesel co-product stream. J Polym Environ 12, 105-112.

Ashby, R.D., Solaiman, D.K.Y. and Foglia, T.A. (2005) Synthesis of short-/medium-chain-length poly(hydroxyalkanoates) blends by mixed culture fermentation of glycerol. Biomacromolecules 6 , 2106-2112.

Braunegg, G., Lefebvre, G. and Genser, K.F. (1998) Polyhydroxyalkanoates, biopolyesters from renewable resources: physiological and engineering aspects. J Biotechnol 65, 127-161.

Cashion, P., Hodler-Franklin, M.A., McCully, J. and Franklin, M. (1977) A rapid method for base ratio determination of bacterial DNA. Anal Biochem 81, 441-466.

De Ley, J., Cattoir, H. and Reynaerts, A. (1970) The quantitative measurement of DNA hybridization renaturation rates. Eur J Biochem 12, 133-142.

Doi, Y. (1990) Microbial Polyesters.

New York : VHC Publishers.

Hankermeyer, C.R. and Tjeerdema, R.S. (1999) Polyhydroxybutyrate: plastic made and degraded by microorganisms. Rev Environ Contam Toxicol 159, 1-24.

Hocking, P.J. and Marchessault, R.H. (1994) Biopolyesters. In Chemistry and Technology of Biodegradable Polymers ed. Griffin, G.J.L. pp. 49-96.

London, UK

: Blackie Academic and Professional.

Huss, V.A.R., Festl, H. and Schleifer, K.H. (1983) Studies on the spectrophotometric determination of DNA hybridization from renaturation rates. Syst Appl Microbiol 4, 184-192.

Jiang, X., Ramsay, J.A. and Ramsay, B.A. (2006) Acetone extraction of mcl-PHA from Pseudomonas putida KT 2440. J Microbiol Methods 67, 212-219.

Koller, M., Bona, R., Braunegg, G., Hermann, C., Horvat, P., Kroutil, M., Martinz, J., Neto, J. et al. (2005) Production of polyhydroxyalkanoates from agricultural waste and surplus materials. Biomacromolecules 6, 561-565.

Langeveen, R.G., Huisman, G.W., Preusting, H., Ketelaar, P., Eggink, G. and Witholt, B. (1988) Formation of polyesters by Pseudomonas oelovorans- effect of substrates on formation and composition of poly-(R)-3-hydroxyalkanoates and poly-(R)-3-hydroxyalkenoates. Appl Environ Microbiol 54, 2924-2932.

Mao Che, L., Andréfouët, S., Bothorel, V., Guezennec, M., Rougeaux, H., Guezennec, J., Deslandes, E., Trichet, J. et al. (2001) Physical, chemical and microbiological characteristics of microbial mats (KOPARA) in the South Pacific atolls of French Polynesia. Can J Microbiol 47, 994-1012.

Nichols, P.D., Guckert, J.B. and White, D.C. (1986) Determination of monounsaturated fatty acid double bond position and geometry for microbial monocultures and complex consortia by capillary GC-MS of their dimethyldisulfur adducts. J Microbiol Methods 5, 49-55. 
Raguénès, G.H.C., Perès, A., Ruimy, R., Pignet, P., Christen, R., Loaec, M., Rougeaux, H., Barbier, G. et al. (1997) Alteromonas infernus sp. nov., a new polysaccharide-producing bacterium isolated from a deep-sea hydrothermal vent. J Appl Microbiol 82, 422-430.

Raguénès, G., Moppert, X., Richert, L., Ratiskol, J., Payri, C., Costa, B. and Guezennec, J. (2004) A novel exopolymer-producing bacterium, Paracoccus zeaxanthinifaciens subsp. payriae, isolated from a "kopara" mat located in Rangiroa, an atoll of French Polynesia. Curr Microbiol 49, 145-151.

Rougeaux, H., Guezennec, M., Mao Che, L., Payri, C., Deslandes, E. and Guezennec, J. (2001) Microbial communities and exopolysaccharides from polynesian mats. Mar Biotechnol 3, 181187.

Solaiman, D.K.Y., Ashby, R.D. and Foglia, T.A. (2001) Production of polyhydroxyalkanoates from intact triacylglycerols by genetically engineered Pseudomonas. Appl Microbiol Biotechnol 56, 664-669.

-

Stackebrandt, E. and Goebel, B.M. (1994) Taxonomic note: a place for DNA-DNA reassociation and 16S rRNA sequence analysis in the present species definition in bacteriology. Int J Syst Bacteriol 44, 846-849.

Steinbüchel, A. and Valentin, H.E. (1995) Diversity of bacterial polyhydroalkanoic acids. FEMS Microbiol Lett 128, 219-228.

Tsuge, T. (2002) Metabolic improvements and use of inexpensive carbon sources in microbial production of polyhydroxyalkanoates. J Biosci Bioeng 94, 579-584.

Wayne, L.G., Brenner, D.J., Colwell, R.R., Grimont, P.A.D., Kandler, O., Krichevesky, M.I., Moore, L.H., Murray, R.G.E. et al. (1987) Report of the Ad Hoc committee on reconciliation of approaches to bacterial systematics. Int J Syst Bacteriol 37, 463-464.

\section{Figures}

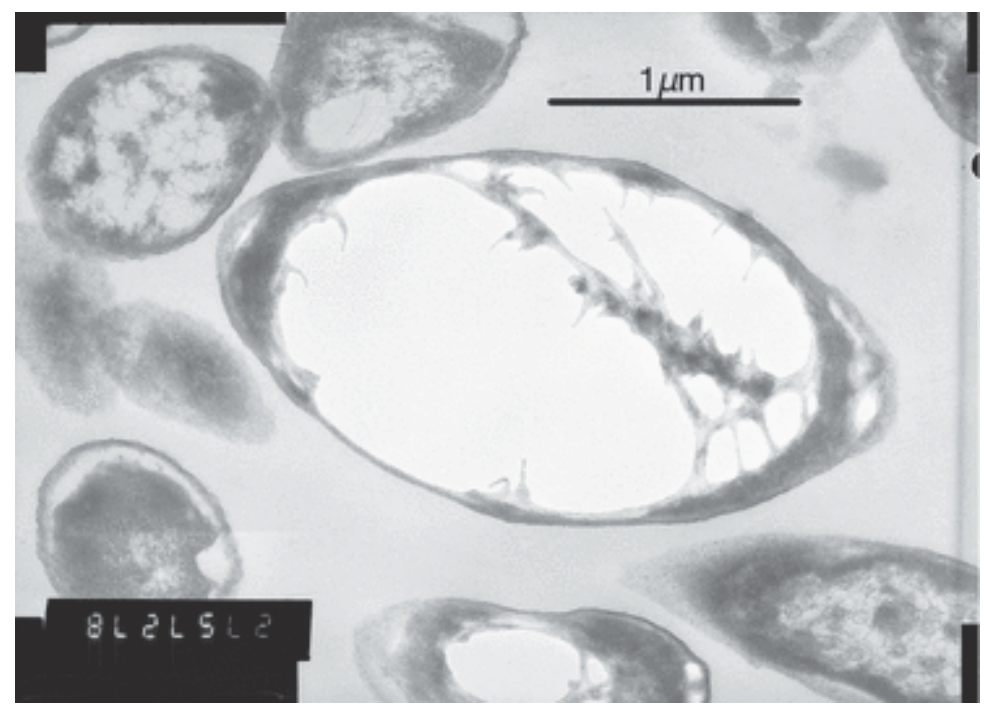

Figure 1 Transmission electron micrograph of strain RA26 grown under conditions of polyhydroxyalkanoate accumulation. Bar represents $1 \mu \mathrm{m}$. 
17 Species, mean length : 1376 (pairwise gap removal)

Jukes and Cantor distance

0.020

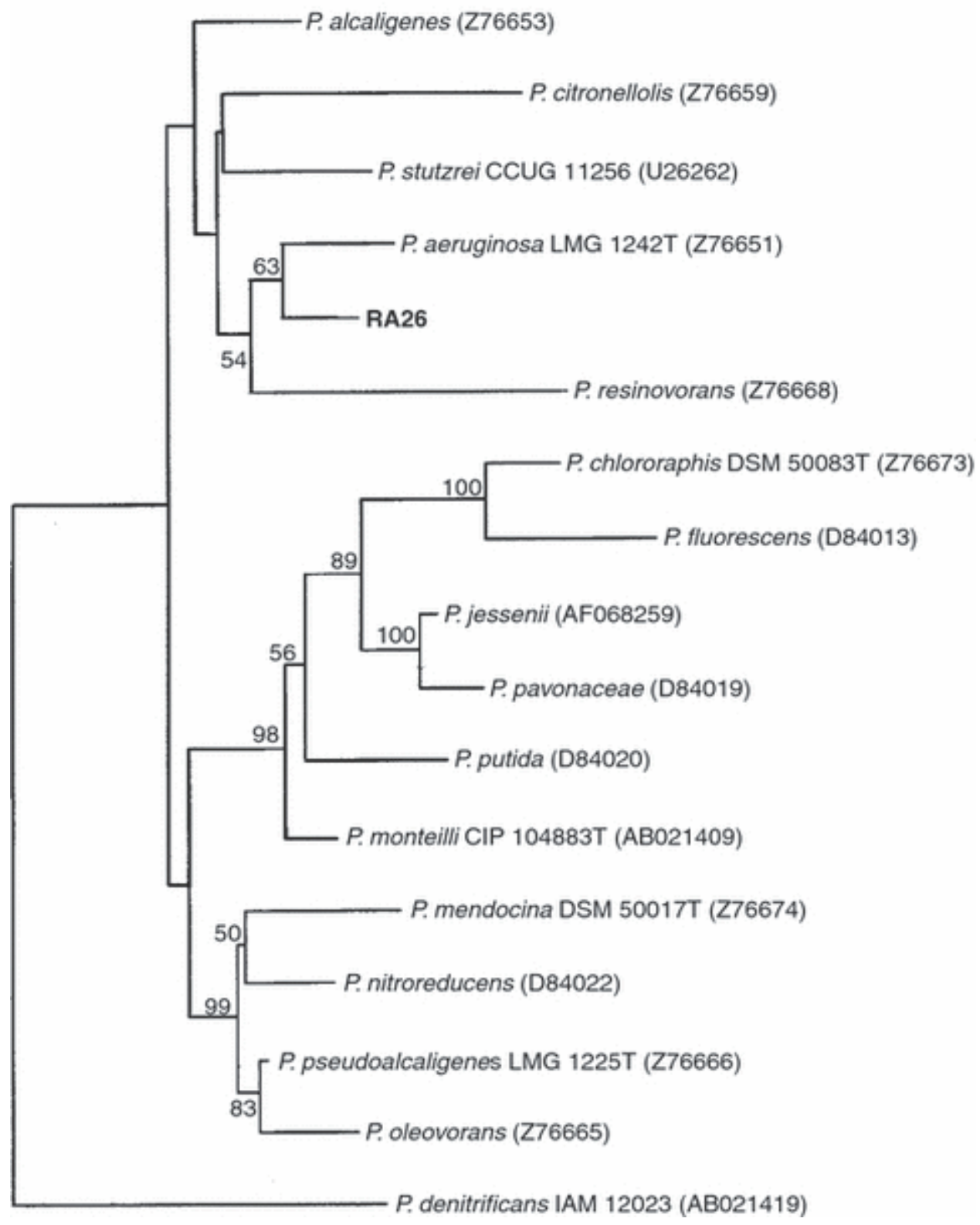

Figure 2 Phylogenetic position of the new bacterium (RA26) within the genera Pseudomonas. 